\title{
IMPLEMENTASI METODE MOORA (MULTI OBJECTIVE OPTIMIZATION ON THE BASIC OF RATIO ANALYSIS) UNTUK REKOMENDASI PEMILIHAN TYPE SEPEDA MOTOR TERBAIK (Studi Kasus : CV. Satu Hati Perkasa)
}

\author{
Nurhayati \\ Program Studi Teknik Informatika, STMIK KAPUTAMA \\ Jl. Veteran No. 4A-9A, Binjai, 20174 Sumatera Utara \\ nurhayati_azura@yahoo.co.id
}

\begin{abstract}
Motorcycle is one of the means of transportation that is loved by the community because it has a small size, fast and the price is not too expensive compared to other transportation equipment. Now many types of motorcycles complete with advantages and advantages. This of course will make it difficult for consumers to make the right choice, according to the desired criteria. To make it easier for buyers to choose the type of motorcycle that suits their needs, a decision support system is designed to recommend the appropriate motorcycle type.This system is built with accurate calculations using the MOORA method (Multi Objective Optimization on The Basic of Ratio Analysis) so that the accuracy of calculations is more guaranteed that is applied using PHP MySQL software. With this system, customers / buyers have no difficulty choosing the type of motorcycle that suits their needs and finances so that it will create a convenient and fast buying and selling process. From the 17 data, it can be seen that the results manually on the recommendation of a motorcycle type can be seen that A_3 is the highest alternative with a value of 27.336773. In other words the A_3 type motorcycle Vario 150 is the best motorcycle.
\end{abstract}

Keywords:, Honda Motorcycles, MOORA (Multi Objective Optimization on The Basic of Ratio Analysis), PHP MySQL, Decision Support Systems.

\begin{abstract}
ABSTRAK
Sepeda motor merupakan salah satu alat transportasi yang di gemari masyarakat karena memiliki ukuran yang kecil, cepat dan harga yang tidak terlalu mahal di bandingkan alat transportasi lainya. Sekarang banyak macam type sepeda motor lengkap dengan keunggulan dan kelebihannya. Hal ini tentunya akan mempersulit konsumen dalam menentukan pilihan yang tepat, sesuai dengan kriteria yang diinginkan. Untuk memudahkan pembeli dalam memilih type sepeda motor yang sesuai dengan keinginannya maka dirancang sebuah sistem pendukung keputusan untuk merekomendasikan type sepeda motor yang sesuai.Sistem ini dibangun dengan perhitungan yang akurat dengan menggunakan metode MOORA (Multi Objective Optimization on The Basic of Ratio Analysis)sehingga akurasi perhitungan lebih terjamin yang diaplikasi dengan menggunakan software PHP MySQL. Dengan adanya sistem ini pelanggan/pembeli tidak kesulitan untuk memilih type sepeda motor yang sesuai dengan kebutuhan dan keuangannya sehingga akan tercipta proses jual beli yang nyaman dan cepat.Dari 17 data dapat diketahui hasil secara manual pada rekomendasi type sepeda motor dapat dilihat bahwa $A_{3}$ merupakan alternatif tertinggi dengan nilai yaitu 27,36773. Dengan kata lain $A_{3}$ tipe sepeda motor Vario 150 merupakan sepeda motor terbaik.
\end{abstract}

Kata Kunci : Sepeda Motor Honda, MOORA (Multi Objective Optimization on The Basic of Ratio Analysis), PHP MySQL, Sistem Pendukung Keputusan. 


\section{PENDAHULUAN}

Kebutuhan alat transportasi pada saat sekarang ini merupakan kebutuhan yang mutlak dalam kehidupan, khususnya alat transportasi pribadi yang sangat dibutuhkan oleh masyarakat untuk melakukan kegiatan sehari-hari. Sepeda motor merupakan alat transportasi yang banyak diminati oleh masyarakat karena kepraktisan sepeda motor bila digunakan pada jalan raya yang padat. Peningkatan penggunaan sepeda motor ditandai dengan semakin banyaknya permintaan sepeda motor dan semakin gencarnya produsen-produsen sepeda motor melakukan inovasi terhadap produknya, sehingga calon pembeli akan menentukan pilihan type sepeda motor yang tepat sesuai dengan kriteria yang diinginkan. Sehingga perlu cara bagaimana memilih type sepeda motor terbaik yang tepat sesuai dengan kriteria yang diinginkan calon pembeli. Sekarang banyak macam varian sepeda motor lengkap dengan keunggulan dan kelebihannya. Hal ini tentunya akan mempersulit konsumen dalam menentukan pilihan yang tepat, sesuai dengan kriteria yang diinginkan. Oleh karena itu solusi yang harus dicapai perlu dibuat sebuah sistem pendukung keputusan yang membantu para pembeli untuk menentukan tipe sepeda motor yang cocok dengan pembeli sesuai dengan kriteria yang ditentukan. Tujuannya adalah Untuk membangun dan menganalisis sistem pendukung keputusan bagaimana impelementasi metode MOORA (Multi Objective Optimization on The Basic of Ratio Analysis) dalam rekomendasi pemilihan type sepeda motor terbaik di CV Satu Hati Perkasa. Untuk mengetahui alternatif terbaik dengan menggunakan metode MOORA (Multi Objective Optimization on The Basic of Ratio Analysis) dalam rekomendasi pemilihan type sepeda motor terbaik berdasarkan kriteria kriteria yang telah ditentukan di CV Satu Hati Perkasa.

\section{TINJAUAN PUSTAKA}

\subsection{Sistem Pendukung Keputusan}

Menyatakan bahwa "Sistem pendukung keputusan atau Decision Support Sistem (DSS) adalah sistem informasi interaktif yang menyediakan informasi, pemodelan, dan pemanipulasian data. Sistem itu digunakan untuk membantu mengambil keputusan dalam situasi yang semiterstruktur dan situasi yang tidak terstruktur, dimana tak seorangpun tahu secara pasti bagaimana keputusan seharusnya dibuat[1]. Pengambilan keputusan dilakukan dengan pendekatan sistematis terhadap permasalahan melalui proses pengumpulan data menjadi informasi serta ditambah dengan faktor - faktor yang perlu dipertimbangkan dalam pengambilan keputusan. Metode MOORA banyak diaplikasikan dalam beberapa bidang seperti bidang manajemen, bangunan, kontraktor, desain jalan, dan ekonomi[2]. Metode ini memiliki tingkat selektifitas yang baik dalam menentukan suatu alternatif. Pendekatan yang dilakukan MOORA didefinisikan sebagai suatu proses secara bersamaanguna mengoptimalkan dua atau lebih yang saling bertentangan pada beberapa kendala.

\subsection{Metode Multi Objective Optimization On The Basic Ofratio Analysis (MOORA)}

Metode Multi Objective Optimization On The Basis Of Ratio Analysis(MOORA) adalah metode yang diperkenalkan oleh Brauers dan Zavadkas. Metode yang relatif baru ini pertama kali digunakan oleh Brauers dalam suatu pengambilan dengan multi criteria[3]. Metode MOORA memiliki tingkat fleksibilitas dan kemudahan untuk dipahami dalam memisahkan bagian subjektif dari suatu proses evaluasi ke dalam kriteria bobot keputusan dengan beberapa atribut pengambilan keputusan. Metode ini memiliki tingkat selektifitas yang baik karena dapat menentukan tujuan dari kriteria yang bertentangan. Dimana kriteria dapat bernilai menguntungkan (benefit) atau yang tidak menguntungkan (cost). 


\section{Penentuan nilai matrik keputusan}

Menentukan tujuan untuk mengidentifikasi atribut evaluasi yang bersangkutan.

$$
\mathrm{X}=\left[\begin{array}{llll}
x_{11} & x_{12} & \cdot & x_{1 n} \\
x_{21} & x_{22} & \cdot & x_{2 n} \\
x_{31} & x_{32} & . & x_{3 n}
\end{array}\right] .
$$

\section{Normalisasi matriks}

Menyimpulkan bahwa untuk atribut, pilihan terbaik adalah akar kuadrat dari jumlah kuadrat dan setiap alternatif per atribut.

$$
x *_{i j=x_{i j}} / \sqrt{\left[\sum_{i=1}^{m} x_{i j}^{2}\right]}(j=1,2, \ldots, n) .
$$

\section{Mengoptimalkan atribut}

Untuk optimasi multi objektif, ukuran yang dinormalisasi ditambahkan dalam kasus maksimasi (untuk atribut yang menguntungkan) dan dikurangi dalam kasus minimasi (untuk atribut yang tidak menguntungkan).

$$
y_{i}=\sum_{j=1}^{g} w_{j} x *_{i j}
$$

Apabila menyertakan bobot dalam pencarian yang ternormalisasi maka rumusnya :

$$
y_{i}=\sum_{j=1}^{g} w_{j} x *_{i j}-\sum_{j=g+1}^{n} w_{j} x *_{i j}(j=1,2 \ldots, n)
$$

\section{Perangkingan nilai Yi}

Nilai Yi bisa positif atau negatif tergantung dari total maksimal dan minimal dalam matriks keputusan. Sebuah urutan peringkat dan Yi menunjukkan pulihan terakhir. Dengan demikian alternatif terbaik memiliki nilai Yi tertinggi, sedangkan alternatif terburuk memiliki nilai yang terendah.

\section{Metode Penelitian}

CV. Satu Hati Perkasa terletak di Brandan tepatnya di Pelawi Utara kec, merupakan sebuah dealer yang berkonsentrasi pada bisnis penjualan sepeda motor dan sekaligus menjadi bengkel resmi yang memberikan kemudahan dan kepuasan pada konsumen yang dapat membeli sepeda motor sekaligus merawat sepeda motor yang telah dibeli. Perusahaan ini merupakan dealer dan servis bengkel resmi sepeda motor merek dagang Honda.

\subsection{Analisis Sistem}

Tujuan utama analisis sistem ini adalah menemukan kesalahan dan kelemahan - kelemahan dari sistem yang sedang berjalan, sehingga dapat diusulkan perbaikannya. Di dalam penelitian ini juga dapat dilakukan analisis terhadap sistem yang sedang di teliti. Hal ini bertujuan agar dapat ditemukan solusi untuk menangani permasalahan - permasalahan yang ada pada sistem tersebut.

\section{Tabel III.1 Kriteria Penentuan Sepeda Motor Honda terbaik}

\begin{tabular}{|c|c|c|}
\hline Kriteria & Keterangan & Bobot \\
\hline C1 & Jenis & 25 \\
\hline C2 & KapasitasMesin & 35 \\
\hline C3 & Varian Warna & 15 \\
\hline C4 & Harga & 25 \\
\hline
\end{tabular}

Tabel III.2 Bobot Kriteria

\begin{tabular}{|c|c|}
\hline Nilai & Keterangan \\
\hline 1 & SangatRendah (SR) \\
\hline 2 & Rendah (R) \\
\hline
\end{tabular}




\begin{tabular}{|c|c|}
\hline 3 & Cukup (C) \\
\hline 4 & Tinggi (T) \\
\hline 5 & SangatTinggi (ST) \\
\hline
\end{tabular}

Tabel III.3 KriteriaJenisSepeda Motor

\begin{tabular}{|c|c|}
\hline JenisSepeda Motor & Nilai \\
\hline Cub & 1 \\
\hline Sport & 2 \\
\hline Matic & 3 \\
\hline
\end{tabular}

Tabel III.4 KriteriaKapasitasMesin Sepeda Motor

\begin{tabular}{|c|c|}
\hline KapasitasMesinSepeda Motor & Nilai \\
\hline $110 \mathrm{CC}$ & 1 \\
\hline $125 \mathrm{CC}$ & 2 \\
\hline $150 \mathrm{CC}$ & 3 \\
\hline
\end{tabular}

Tabel III.5 KriteriaVarian Warna Sepeda Motor

\begin{tabular}{|c|c|}
\hline Varian Warna Sepeda Motor & Nilai \\
\hline$<2$ Varian Warna & 1 \\
\hline 3 - 4 Varian Warna & 2 \\
\hline 5 - 6 Varian Warna & 3 \\
\hline 7 - 8 Varian Warna & 4 \\
\hline$>9$ Varian Warna & 5 \\
\hline
\end{tabular}

Tabel III.6 Kriteria Harga Sepeda Motor

\begin{tabular}{|c|c|}
\hline Harga Sepeda Motor & Nilai \\
\hline Rp. 26.000.000 - Rp. 28.999.999 & 1 \\
\hline Rp. 23.000.000 - Rp. 25.999.999 & 2 \\
\hline Rp.20.000.000 - Rp. 22.999.9999 & 3 \\
\hline Rp. 17.000.000 - Rp. 19.999.999 & 4 \\
\hline Rp. 14.000.000 - Rp. 16.999.999 & 5 \\
\hline
\end{tabular}

Tabel III.7 Data Sepeda Motor

\begin{tabular}{|c|l|c|c|l|l|}
\hline $0-=$ & $\begin{array}{l}\text { TipeSepeda } \\
\text { Motor }\end{array}$ & Jenis & KapasitasMesin & \multicolumn{1}{|c|}{ Warna } & Harga \\
\hline A1 & $\begin{array}{l}\text { VARIO 125 } \\
\text { CBS }\end{array}$ & Matic & $125 \mathrm{cc}$ & $\begin{array}{l}\text { Hitam; } \\
\text { PutihBiru; } \\
\text { HitamMerah }\end{array}$ & $\begin{array}{l}\text { Rp } \\
20.300 .000\end{array}$ \\
\hline A2 & $\begin{array}{l}\text { VARIO 125 } \\
\text { CBS ISS }\end{array}$ & Matic & $125 \mathrm{cc}$ & $\begin{array}{l}\text { Merah; } \\
\text { Hitam; } \\
\text { PutihMerah; } \\
\text { HitamKuning; } \\
\text { HitamHijau }\end{array}$ & $\begin{array}{l}\text { Rp } \\
21.050 .000\end{array}$ \\
\hline A3 & VARIO 150 & Matic & $150 \mathrm{cc}$ & $\begin{array}{l}\text { Merah; Putih; } \\
\text { Hitam; } \\
\text { Silver ; Biru ; } \\
\text { Coklat }\end{array}$ & $\begin{array}{l}\text { Rp } \\
23.480 .000\end{array}$ \\
\hline A4 & $\begin{array}{l}\text { BEAT } \\
\text { SPORTY }\end{array}$ & Matic & $110 \mathrm{cc}$ & $\begin{array}{l}\text { PutihBiru; } \\
\text { PutihMerah; }\end{array}$ & $\begin{array}{l}\text { Rp } \\
16.680 .000\end{array}$ \\
\hline
\end{tabular}


JURNAL TEKNOLOGI DAN OPEN SOURCE

VOL. 3 No. 1, Juni $2020: 101$ - 113

\begin{tabular}{|c|c|c|c|c|c|}
\hline & CBS & & & $\begin{array}{l}\text { HitamHijau; } \\
\text { MerahPutih; } \\
\text { Hitam }\end{array}$ & \\
\hline A5 & $\begin{array}{l}\text { BEAT } \\
\text { SPORTY } \\
\text { CW }\end{array}$ & Matic & $110 \mathrm{cc}$ & $\begin{array}{l}\text { HitamMerah ; } \\
\text { Hitam ; } \\
\text { PutihBiru ; } \\
\text { Putih }\end{array}$ & $\begin{array}{l}\mathrm{Rp} \\
16.480 .000\end{array}$ \\
\hline A6 & $\begin{array}{l}\text { BEAT } \\
\text { STREET }\end{array}$ & Matic & $110 \mathrm{cc}$ & $\begin{array}{l}\text { Hitam ; Putih ; } \\
\text { PutihBiru }\end{array}$ & $\begin{array}{l}\mathrm{Rp} \\
17.250 .000\end{array}$ \\
\hline A7 & $\begin{array}{l}\text { BEAT } \\
\text { SPORTY } \\
\text { CBS ISS }\end{array}$ & Matic & $110 \mathrm{cc}$ & $\begin{array}{l}\text { Magenta ; } \\
\text { Magenta } \\
\text { Hitam ; } \\
\text { BiruPutih ; } \\
\text { PutihMerah ; } \\
\text { Merah ; } \\
\text { PutihBiru }\end{array}$ & $\begin{array}{l}\mathrm{Rp} \\
17.180 .000\end{array}$ \\
\hline A8 & SCOOPY & Matic & $110 \mathrm{cc}$ & $\begin{array}{l}\text { MerahHitam; } \\
\text { Hitam ; } \\
\text { CoklatHitam ; } \\
\text { Merah ; } \\
\text { PutihHitam ; } \\
\text { Putih ; Hitam } \\
\text { Silver ; } \\
\text { PutihHijau }\end{array}$ & $\begin{array}{l}\mathrm{Rp} \\
18.980 .000\end{array}$ \\
\hline A9 & $\begin{array}{l}\text { SUPRA } \\
\text { SPOKE }\end{array}$ & $\mathrm{Cub}$ & $125 \mathrm{cc}$ & $\begin{array}{l}\text { MerahHitam; } \\
\text { Hitam }\end{array}$ & $\begin{array}{l}\mathrm{Rp} \\
18.010 .000 \\
\end{array}$ \\
\hline A10 & $\begin{array}{l}\text { SUPRA } \\
\text { CW }\end{array}$ & $\mathrm{Cub}$ & $125 \mathrm{cc}$ & Hitam ; Merah & $\begin{array}{l}\mathrm{Rp} \\
19.060 .000\end{array}$ \\
\hline A11 & REVO FIT & $\mathrm{Cub}$ & $110 \mathrm{cc}$ & $\begin{array}{l}\text { HitamMerah ; } \\
\text { HitamBiru ; } \\
\text { HitamHijau }\end{array}$ & $\begin{array}{l}\mathrm{Rp} \\
14.880 .000\end{array}$ \\
\hline A12 & $\begin{array}{l}\text { CB150 } \\
\text { VERZA }\end{array}$ & Sport & $150 \mathrm{cc}$ & $\begin{array}{l}\text { Hitam; } \\
\text { Silver; } \\
\text { Merah; } \\
\text { HitamMerah }\end{array}$ & $\begin{array}{l}\mathrm{Rp} \\
20.050 .000\end{array}$ \\
\hline A13 & CB150R & Sport & $150 \mathrm{cc}$ & $\begin{array}{l}\text { HitamHijau; } \\
\text { HitamMerah ; } \\
\text { Hitam ; } \\
\text { Merah ; } \\
\text { HitamKuning }\end{array}$ & $\begin{array}{l}\mathrm{Rp} \\
27.130 .000\end{array}$ \\
\hline A14 & CB150R SE & Sport & $150 \mathrm{cc}$ & Merah; Hitam & $\begin{array}{l}\mathrm{Rp} \\
28.230 .000\end{array}$ \\
\hline A15 & $\begin{array}{l}\text { VERZA } \\
\text { CW }\end{array}$ & Sport & $150 \mathrm{cc}$ & $\begin{array}{l}\text { HitamMerah ; } \\
\text { BiruPutih ; } \\
\text { HitamBiru }\end{array}$ & $\begin{array}{l}\mathrm{Rp} \\
20.520 .000\end{array}$ \\
\hline A16 & $\begin{array}{l}\text { VERZA } \\
\text { SPOKE }\end{array}$ & Sport & $150 \mathrm{cc}$ & $\begin{array}{l}\text { HitamMerah ; } \\
\text { HitamBiru }\end{array}$ & $\begin{array}{l}\mathrm{Rp} \\
19.810 .000\end{array}$ \\
\hline A17 & $\begin{array}{l}\text { VARIO } 110 \\
\text { CBS }\end{array}$ & Matic & $110 \mathrm{cc}$ & Hitam & $\begin{array}{l}\mathrm{Rp} \\
17.700 .000\end{array}$ \\
\hline
\end{tabular}

Tabel III.8 Data Rating Kecocokan Bobot dan Kriteria

\begin{tabular}{|c|l|c|c|c|c|}
\hline \multirow{2}{*}{ Alternatif } & Jenis & KapasitasMesin & Warna & Harga \\
\hline A1 & VARIO 125 CBS & 3 & 2 & 2 & 3 \\
\hline A2 & VARIO 125 CBS ISS & 3 & 2 & 3 & 3 \\
\hline A3 & VARIO 150 & 3 & 3 & 3 & 2 \\
\hline A4 & BEAT SPORTY CBS & 3 & 1 & 3 & 5 \\
\hline A5 & BEAT SPORTY CW & 3 & 1 & 2 & 5 \\
\hline A6 & BEAT STREET & 3 & 1 & 2 & 4 \\
\hline A7 & BEAT SPORTY CBS ISS & 3 & 1 & 3 & 4 \\
\hline A8 & SCOOPY & 3 & 1 & 4 & 4 \\
\hline A9 & SUPRA SPOKE & 1 & 2 & 1 & 4 \\
\hline A10 & SUPRA CW & 1 & 2 & 1 & 4 \\
\hline
\end{tabular}




\begin{tabular}{|c|l|c|c|c|c|}
\hline A11 & REVO FIT & 1 & 1 & 2 & 5 \\
\hline A12 & CB150 VERZA & 2 & 3 & 2 & 3 \\
\hline A13 & CB150R & 2 & 3 & 3 & 1 \\
\hline A14 & CB150R SE & 2 & 3 & 1 & 1 \\
\hline A15 & VERZA CW & 2 & 3 & 2 & 3 \\
\hline A16 & VERZA SPOKE & 2 & 3 & 1 & 4 \\
\hline A17 & VARIO 110 CBS & 3 & 1 & 1 & 4 \\
\hline
\end{tabular}

1. Membuat Matriks Keputusan $X_{i j}$

$$
X=\left[\begin{array}{llll}
3 & 2 & 2 & 3 \\
3 & 2 & 3 & 3 \\
3 & 3 & 3 & 2 \\
3 & 1 & 3 & 5 \\
3 & 1 & 2 & 5 \\
3 & 1 & 2 & 4 \\
3 & 1 & 3 & 4 \\
3 & 1 & 4 & 4 \\
1 & 2 & 1 & 4 \\
1 & 2 & 1 & 4 \\
1 & 1 & 2 & 5 \\
2 & 3 & 2 & 3 \\
2 & 3 & 3 & 1 \\
2 & 3 & 1 & 1 \\
2 & 3 & 2 & 3 \\
2 & 3 & 1 & 4 \\
3 & 1 & 1 & 4
\end{array}\right]
$$

2. Normalisasi Matriks $X$

$$
\begin{aligned}
& \mathrm{C} 1=\sqrt{3^{2}+3^{2}+3^{2}+3^{2}+3^{2}+3^{2}+3^{2}+3^{2}+1^{2}}=10,1980 \\
& A_{1}=\frac{3}{10,1980}=0,29417 \\
& A_{2}=\frac{3}{10,1980}=0,29417 \\
& A_{3}=\frac{3}{10,1980}=0,29417 \\
& A_{4}=\frac{3}{10,1980}=0,29417 \\
& A_{5}=\frac{3}{10,1980}=0,29417 \\
& A_{6}=\frac{3}{10,1980}=0,29417 \\
& A_{7}=\frac{3}{10,1980}=0,29417 \\
& A_{8}=\frac{3}{10,1980}=0,29417 \\
& A_{9}=\frac{1}{10,1980}=0,09806 \\
& A_{10}=\frac{1}{10,1980}=0,09806
\end{aligned}
$$




$$
\begin{aligned}
& A_{11}=\frac{1}{10,1980}=0,09806 \\
& A_{12}=\frac{2}{10,1980}=0,19612 \\
& A_{13}=\frac{2}{10,1980}=0,19612 \\
& A_{14}=\frac{2}{10,1980}=0,19612 \\
& A_{15}=\frac{2}{10,1980}=0,19612 \\
& A_{16}=\frac{2}{10,1980}=0,19612 \\
& A_{17}=\frac{3}{10,1980}=0,29417
\end{aligned}
$$

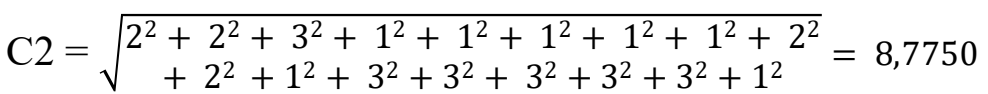

$$
\begin{aligned}
& A_{1}=\frac{2}{8,7750}=0,22792 \\
& A_{2}=\frac{2}{8,7750}=0,22792 \\
& A_{3}=\frac{3}{8,7750}=0,34188 \\
& A_{4}=\frac{1}{8,7750}=0,11396 \\
& A_{5}=\frac{1}{8,7750}=0,11396 \\
& A_{6}=\frac{1}{8,7750}=0,11396 \\
& A_{7}=\frac{1}{8,7750}=0,11396 \\
& A_{8}=\frac{1}{8,7750}=0,11396 \\
& A_{9}=\frac{2}{8,7750}=0,22792 \\
& A_{10}=\frac{2}{8,7750}=0,22792 \\
& A_{11}=\frac{1}{8,7750}=0,11396 \\
& A_{12}=\frac{3}{8,7750}=0,34188 \\
& A_{13}=\frac{3}{8,7750}=0,34188 \\
& A_{14}=\frac{3}{8,7750}=0,34188 \\
& A_{15}=\frac{3}{8,7750}=0,34188 \\
& A_{16}=\frac{3}{8,7750}=0,34188
\end{aligned}
$$




$$
\begin{aligned}
& A_{17}=\frac{1}{8,7750}=0,11396 \\
& \mathrm{C} 3=\sqrt{\begin{array}{c}
2^{2}+3^{2}+3^{2}+3^{2}+2^{2}+2^{2}+3^{2}+4^{2}+1^{2} \\
+1^{2}+2^{2}+2^{2}+3^{2}+1^{2}+2^{2}+1^{2}+1^{2}
\end{array}=9,4868} \\
& A_{1}=\frac{2}{9,4868}=0,21082 \\
& A_{2}=\frac{3}{9,4868}=0,31623 \\
& A_{3}=\frac{3}{9,4868}=0,31623 \\
& A_{4}=\frac{3}{9,4868}=0,31623 \\
& A_{5}=\frac{2}{9,4868}=0,21082 \\
& A_{6}=\frac{2}{9,4868}=0,21082 \\
& A_{7}=\frac{3}{9,4868}=0,31623 \\
& A_{8}=\frac{4}{9,4868}=0,42164 \\
& A_{9}=\frac{1}{9,4868}=0,10541 \\
& A_{10}=\frac{1}{9,4868}=0,10541 \\
& A_{11}=\frac{2}{9,4868}=0,21082 \\
& A_{12}=\frac{2}{9,4868}=0,21082 \\
& A_{13}=\frac{3}{9,4868}=0,31623 \\
& A_{14}=\frac{1}{9,4868}=0,10541 \\
& A_{15}=\frac{2}{9,4868}=0,21082 \\
& A_{16}=\frac{1}{9,4868}=0,10541 \\
& A_{17}=\frac{1}{9,4868}=0,10541 \\
& \mathrm{C} 4=\sqrt{\begin{array}{c}
3^{2}+3^{2}+2^{2}+5^{2}+5^{2}+4^{2}+4^{2}+4^{2}+4^{2} \\
+4^{2}+5^{2}+3^{2}+1^{2}+1^{2}+3^{2}+4^{2}+4^{2}
\end{array}=15,1327} \\
& A_{1}=\frac{3}{15,1327}=0,19825 \\
& A_{2}=\frac{3}{15,1327}=0,19825 \\
& A_{3}=\frac{2}{15,1327}=0,13216
\end{aligned}
$$




$$
\begin{aligned}
& A_{4}=\frac{5}{15,1327}=0,33041 \\
& A_{5}=\frac{5}{15,1327}=0,33041 \\
& A_{6}=\frac{4}{15,1327}=0,26433 \\
& A_{7}=\frac{4}{15,1327}=0,26433 \\
& A_{8}=\frac{4}{15,1327}=0,26433 \\
& A_{9}=\frac{4}{15,1327}=0,26433 \\
& A_{10}=\frac{4}{15,1327}=0,26433 \\
& A_{11}=\frac{5}{15,1327}=0,33041 \\
& A_{12}=\frac{3}{15,1327}=0,19825 \\
& A_{13}=\frac{1}{15,1327}=0,06608 \\
& A_{14}=\frac{1}{15,1327}=0,06608 \\
& A_{15}=\frac{3}{15,1327}=0,19825 \\
& A_{16}=\frac{4}{15,1327}=0,26433 \\
& A_{17}=\frac{4}{15,1327}=0,26433 \\
& D a 19
\end{aligned}
$$

Dari hasil perhitungan diatas maka di dapat hasil Normalisasi Matriks $X_{i j}$, yaitu :

$X=\left[\begin{array}{llll}0,29417 & 0,22792 & 0,21082 & 0,19825 \\ 0,29417 & 0,22792 & 0,31623 & 0,19825 \\ 0,29417 & 0,34188 & 0,31623 & 0,13216 \\ 0,29417 & 0,11396 & 0,31623 & 0,33041 \\ 0,29417 & 0,11396 & 0,21082 & 0,33041 \\ 0,29417 & 0,11396 & 0,21082 & 0,26433 \\ 0,29417 & 0,11396 & 0,31623 & 0,26433 \\ 0,29417 & 0,11396 & 0,42164 & 0,26433 \\ 0,09806 & 0,22792 & 0,10541 & 0,26433 \\ 0,09806 & 0,22792 & 0,10541 & 0,26433 \\ 0,09806 & 0,11396 & 0,21082 & 0,33041 \\ 0,19612 & 0,34188 & 0,21082 & 0,19825 \\ 0,19612 & 0,34188 & 0,31623 & 0,06608 \\ 0,19612 & 0,34188 & 0,10541 & 0,06608 \\ 0,19612 & 0,34188 & 0,21082 & 0,19825 \\ 0,19612 & 0,34188 & 0,10541 & 0,26433 \\ 0,29417 & 0,11396 & 0,10541 & 0,26433\end{array}\right]$

3. Menentukan Matriks Normalisasi Terbobot 


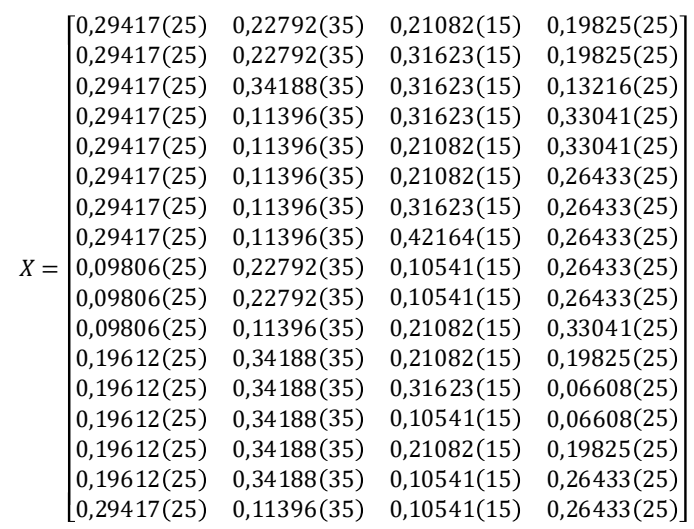

Hasil Perkalian dengan Bobot Kriteria

$X=\left[\begin{array}{cccc}7,35436 & 7,97724 & 3,16228 & 4,95614 \\ 7,35436 & 7,97724 & 4,74342 & 4,95614 \\ 7,35436 & 11,96586 & 4,74342 & 3,30409 \\ 7,35436 & 3,98862 & 4,74342 & 8,26023 \\ 7,35436 & 3,98862 & 3,16228 & 8,26023 \\ 7,35436 & 3,98862 & 3,16228 & 6,60819 \\ 7,35436 & 3,98862 & 4,74342 & 6,60819 \\ 7,35436 & 3,98862 & 6,32456 & 6,60819 \\ 2,45145 & 7,97724 & 1,58114 & 6,60819 \\ 2,45145 & 7,97724 & 1,58114 & 6,60819 \\ 2,45145 & 3,98862 & 3,16228 & 8,26023 \\ 4,90290 & 11,96586 & 3,16228 & 4,95614 \\ 4,90290 & 11,96586 & 4,74342 & 1,65205 \\ 4,90290 & 11,96586 & 1,58114 & 1,65205 \\ 4,90290 & 11,96586 & 3,16228 & 4,95614 \\ 4,90290 & 11,96586 & 1,58114 & 6,60819 \\ 7,35436 & 3,98862 & 1,58114 & 6,60819\end{array}\right]$

4. Mencari Nilai Yi

Tabel III.16 Daftar Yi

\begin{tabular}{|c|c|c|}
\hline Alternatif & $\begin{array}{c}\text { Tipe Sepeda } \\
\text { Motor }\end{array}$ & Yi \\
\hline A1 & VARIO 125 CBS & 23,45001 \\
\hline A2 & $\begin{array}{c}\text { VARIO 125 CBS } \\
\text { ISS }\end{array}$ & 25,03115 \\
\hline A3 & VARIO 150 & 27,36773 \\
\hline A4 & $\begin{array}{c}\text { BEAT SPORTY } \\
\text { CBS }\end{array}$ & 24,34662 \\
\hline A5 & BEAT SPORTY & 22,76549 \\
\hline A6 & CW & 21,11344 \\
\hline A 7 & $\begin{array}{c}\text { BEAT STREET } \\
\text { CBS ISS }\end{array}$ & 22,69458 \\
\hline A8 & SCOOPY & 24,27572 \\
\hline A9 & SUPRA SPOKE & 18,61802 \\
\hline A10 & SUPRA CW & 18,61802 \\
\hline A11 & REVO FIT & 17,86258 \\
\hline A12 & CB150 VERZA & 24,98718 \\
\hline A13 & CB150R & 23,26423 \\
\hline A14 & CB150R SE & 20,10195 \\
\hline A15 & VERZA CW & 24,98718 \\
\hline A16 & VERZA SPOKE & 25,05809 \\
\hline A17 & VARIO 110 CBS & 19,53230 \\
\hline & & \\
\hline
\end{tabular}


Dari hasil diatas, dapat dilihat rangking setiap alternatif dari perhitungan kriteria terhadap penentuan type sepeda motor honda pada tabel berikut:

\section{Tabel III.17 Hasil Rangking}

\begin{tabular}{|c|l|c|c|}
\hline No & \multicolumn{1}{|c|}{ Tipe Sepeda Motor } & Yi & Ranking \\
\hline A3 & VARIO 150 & 27,36773 & 1 \\
\hline A16 & VERZA SPOKE & 25,05809 & 2 \\
\hline A2 & VARIO 125 CBS ISS & 25,03115 & 3 \\
\hline A12 & CB150 VERZA & 24,98718 & 4 \\
\hline A15 & VERZA CW & 24,98718 & 5 \\
\hline A4 & BEAT SPORTY CBS & 24,34662 & 6 \\
\hline A8 & SCOOPY & 24,27572 & 7 \\
\hline A1 & VARIO 125 CBS & 23,45001 & 8 \\
\hline A13 & CB150R & 23,26423 & 9 \\
\hline A5 & BEAT SPORTY CW & 22,76549 & 10 \\
\hline No & Tipe Sepeda Motor & Yi & Ranking \\
\hline A7 & BEAT SPORTY CBS ISS & 22,69458 & 11 \\
\hline A6 & BEAT STREET & 21,11344 & 12 \\
\hline A14 & CB150R SE & 20,10195 & 13 \\
\hline A17 & VARIO 110 CBS & 19,53230 & 14 \\
\hline A9 & SUPRA SPOKE & 18,61802 & 15 \\
\hline A10 & SUPRA CW & 18,61802 & 16 \\
\hline A11 & REVO FIT & 17,86258 & 17 \\
\hline & & & \\
\hline
\end{tabular}

Dari hasil perhitungan di atas, dapat dilihat bahwa $A_{3}$ merupakan alternatif tertinggi dengan nilai yaitu 27,36773.Dengan kata lain $A_{3}$ tipesepeda motor Vario 150 merupakansepeda motor terbaik.

\subsection{Use Case}

Diagram ini digunakan untuk menggambarkan pengguna aplikasi dan perilaku pengguna terhadap aplikasi[5]. Berikut gambar III.3 diagram use case adalah sebagai berikut :

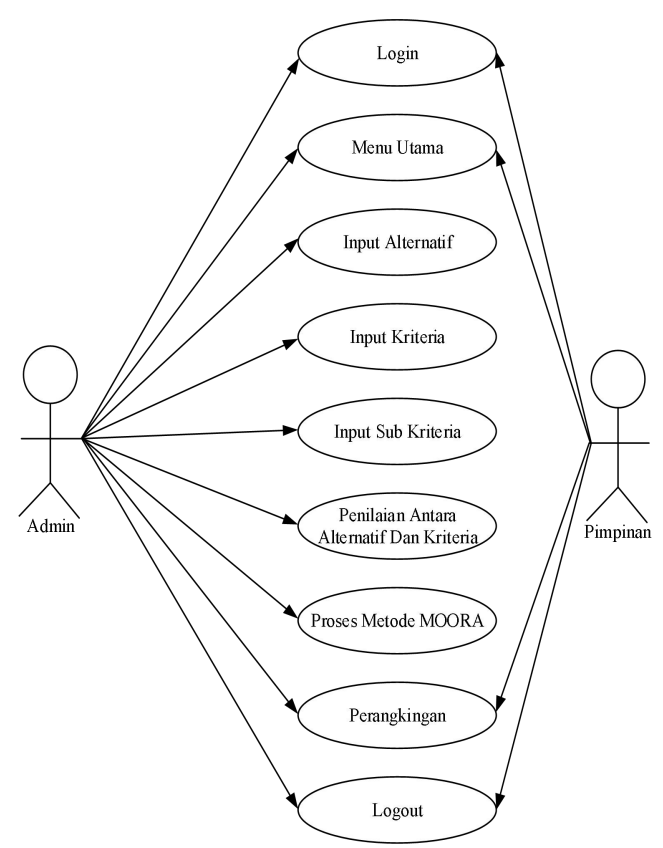

Gambar III.1 Diagram Use Case 


\section{HASIL DAN PEMBAHASAN}

Aplikasi yang dibuat akan ditetapkan berdasarkan dengan kebutuhan. Selain itu aplikasi ini akan dibuat sedemikian rupa sehingga dapat memudahkan pengguna untuk menggunakan aplikasi Implementasi Metode MOORA (Multi Objective Optimization on The Basic of Ratio Analysis) Untuk Rekomendasi Pemilihan Type Sepeda Motor Terbaik[4]. Berikut ini merupakan tampilan hasil perancangan Implementasi Metode MOORA (Multi Objective Optimization on The Basic of Ratio Analysis) Untuk Rekomendasi Pemilihan Type Sepeda Motor Terbaik :

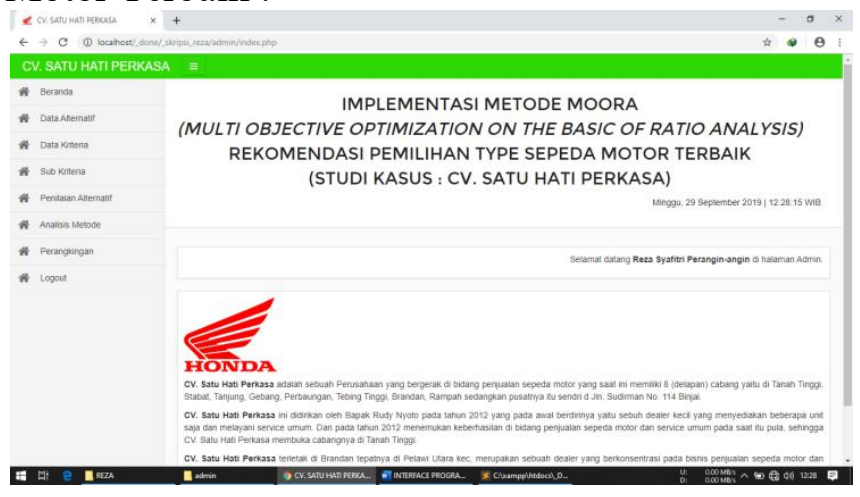

Hasil Analisa MOORA

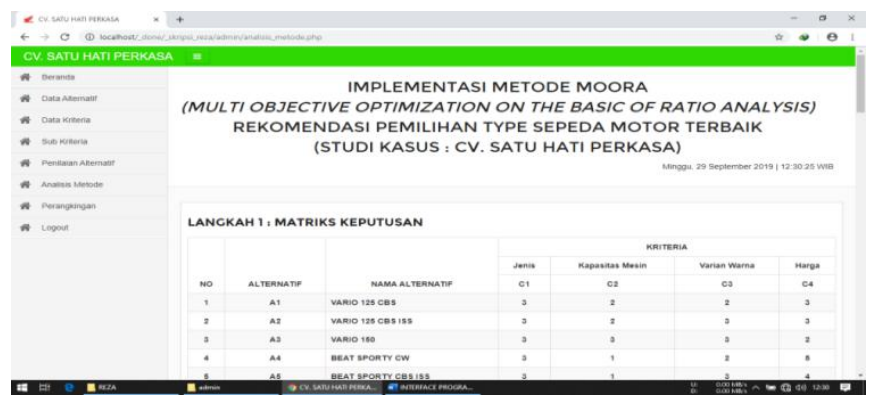

\section{KESIMPULAN}

Berikut ini merupakan kesimpulan yang dapat penulis ambil dari penelitian skripsi ini yaitu :

1. Sistem yang digunakan untuk memberikan sebuah informasi mengenai Rekomendasi Pemilihan Type Sepeda Motor Terbaik, sehingga dapat membantu pihak yang membutuhkan dalam mengambil keputusan sesuai dengan kriteria yang ada.

2. Sistem ini dapat menilai dan memutuskan dalam pemilihan type sepeda motor di CV. Satu Hati Perkasa.

Dari hasil pengujian yang telah dilakukan perhitungannya dengan 17 alternatif dapat dilihat bahwa $A_{3}$ merupakan alternatif tertinggi dengan nilai yaitu 27,36773. Dengan kata lain $A_{3}$ tipe sepeda motor Vario 150 merupakan sepeda motor terbaik.

\section{UCAPAN TERIMAKASIH}

Puji dan syukur penulis ucapkan kehadirat Allah SWT yang telah memberikan kesehatan dan kesempatan kepada peneliti. Penulis menyadari bahwa penelitian ini masih jauh dari kata sempurna, oleh karena itu dengan kerendahan hati penulis sangat berharap kritik dan saran yang bersifat membangun untuk kesempurnaan penelitian berikutnya. maka dengan penuh keikhlasan penulis mengucapkan terima kasih yang sebesar-besarnya kepada Pimpinan dan karyawan cv. satu hati perkasa 


\section{DAFTAR PUSTAKA}

[1] Alvita, Suha dkk. Sistem Pendukung Keputusan Pemilihan Mekanik Sepeda Motor Terbaik Menggunakan Metode Moora. Volume 5 No.1, Februari 2018, ISSN : 2407$389 X$.

[2] Andini, Ari dkk. Penerapan Sistem Pendukung Keputusan Pemilihan Ban Sepeda Motor Honda Dengan Metode MOORA. Volume 5 No.1 Februari 2018, ISSN : 2407 - 389X.

[3] Kusuma, Ardi dkk. Sistem Pendukung Keputusan Pemilihan Siswa/I Teladan Dengan Menggunakan Metode MOORA. Volume 5 No.2 April 2018, ISSN : 2407 - 389X.

[4] Ladjamudin, 2005. Al-Bahra, Analisis dan Desain Sistem Informasi. Yogyakarta, Graha Ilmu.

[5] Sugiarti, Yuni. 2013. Analisis dan Perancangan UML (Unified Modeling Language) Generated VB.6. Graha Ilmu, Yogyakarta. 